\title{
FEEDBACK-BASED CONTINUOUS IMPROVEMENT MEASURES ON THE USE OF SHORT MATHEMATICAL VIDEOS IN UNIVERSITY EDUCATION
}

\author{
Maria del Carmen Bas, Joan Albert Silvestre-Cerdà, Ramon Sala, Robert \\ Meneu, Trinidad Casasús, Rafael Benítez
}

Departament de Matemàtiques per a l'Economia i l'Empresa, Universitat de València (SPAIN)

\begin{abstract}
The main objective of this work is to make a proposal for continuous improvement on the use of short educational videos in order to improve the teaching-learning process at Mathematics I, a university subject present in the curriculum of several social-economical degrees such as Business Administration, Economics, or International Business at the Universitat de València (Spain). In order to enhance the quality of this process, it is necessary to make inquiries of the impressions that the students have about it. In this particular case, we wanted to know the perception that students had after the use of short educational videos of applied mathematics contents during the course. These videos were carefully created by their professors in order to promote autonomous and active learning. Thus, we developed an opinion survey to gather their opinions. This survey measured the students' perception on the degree of usefulness of the teaching materials of the subject and, in particular, the degree of satisfaction on the short educational videos. The results show that, in general, there is a high degree of satisfaction in the use of these videos for self-learning of mathematical concepts. Suggestions from the students allowed us to adopt improvement measures devoted to upgrade the quality of the teaching-learning process.
\end{abstract}

Keywords: continuous improvement, teaching-learning process, video lectures, learning resources.

\section{INTRODUCTION}

Institutions of higher education have experienced various changes conditioned by the demands of today's society. In particular, the widespread use of Information and Communication Technologies (ICT) in the field of higher education is a factor that has led to a change in the application of teaching methodologies, and a need to adapt and make flexible the educational offer to the current reality.

These new changes require teachers to renew their organization of subjects and a reflection on how to introduce new technologies, so appreciated by university students, in their subjects with the aim of improving the learning outcomes of students. One of the main tasks of the teaching staff is to get the students acquire the ability to continue learning to reason, to think, to deduce and to infer knowledge adapting to the new teaching-learning methodologies of the new digital era [1].

Sometimes it is difficult for the student to participate actively and autonomously in their learning, due to the lack of interest and motivation, causing a decrease in their academic performance [2]. With the introduction of the new degrees, students are expected to be the protagonist of their own learning, which will be able to prepare independently part of the contents of the subject [3] [4]. However, these purposes must be accompanied by an appropriate restructuring of the education system, so that they are successful.

The problems typically faced by teachers in order to change the teaching system, so that the student is the protagonist of their own learning, are, on the one hand, the lack of existing time to treat all theoretical and practical contents of the program; and on the other hand, the potential basic deficiencies that the students have at the beginning of the subject and which the professor cannot cover as prerequisites. For that reason, it is very important to provide students with quality teaching materials that allow them to prepare the subject in an active and autonomous way. Although traditionally notes, books, practice scripts, bibliography, etc. have been provided. The current context requires going beyond the generation of teaching material. In this project, we proposed the use of videos as a complementary material in order to apply the flipped-classroom methodology in some basic techniques of mathematics. Johnson et al. [5] provide an overview of current short-term and long-term trends regarding how technology is affecting higher education and consider the integration of online, hybrid and collaborative learning to be a fast trend, driving changes in higher education over 
the next one to two years. The increased use of video as a teaching medium is encroaching onto traditional face-to face teaching in higher education. This affects lecturers, students, Universities and Colleges and there is a need to bridge the gap in digital competencies [6].

\section{METHODOLOGY}

The purpose of this study is to introduce the use of videos as a complementary material in order to apply the flipped-classroom methodology in some basic techniques of mathematics. The flippedclassroom methodology consists in converting the traditional teaching model into a teaching model in which a set of materials are used online thanks to the support of ICTs, which the student must consult before attending the sessions of the attending classrooms. In this way, the classroom sessions become practical classes where the student must work actively, and the teacher must act as a guide.

Among the advantages of the flipped-classroom methodology, we can highlight a greater involvement of the student, a more significant and collaborative learning, a greater adaptation to the rhythm of each student, a greater use of attending classroom hours to solve doubts and a more flexible learning and with new approaches thanks to the support of the technology.

The videos can also be used to reinforce the subject and prepare the evaluation of the subject. In addition, they will contribute to the acquisition of three of the generic competences that appear in the teaching guide of the subject: the ability to work in teams, the ability to use ICT in the field of study and the capacity of autonomous learning.

\section{RESULTS}

The subject involved is "Mathematics I", which includes many algorithmic processes, such as the resolution of systems, the calculation of determinants, inverse of matrices, etc., so the use of educational videos will be great utility to work more content in class in a more active way. Given that this subject is present in various degrees (Business Administration and Management -BAM and Economics - ECO) the impact of the project will be high. We developed an opinion survey to gather the students' perception on the degree of usefulness of the teaching materials of the subject and, in particular, the degree of satisfaction on the short educational videos. Next, the results of the survey, divided into three parts, are presented: characterization of the sample, satisfaction results regarding the use of short educational videos for the preparation of the subject, and aspects of improvement.

\subsection{Sample characteristics}

Figure 1 shows that most of the students surveyed $(N=157)$ regularly attend class $(85.98 \%)$, while the rest are students who do not attend class and, therefore, prepare the subject autonomously. Of the total number of students surveyed, $61.14 \%$ are students of BAM, while $38.85 \%$ of ECO. Observing the figure, we could conclude that there are many more students who do not attend class in BAM than in ECO.

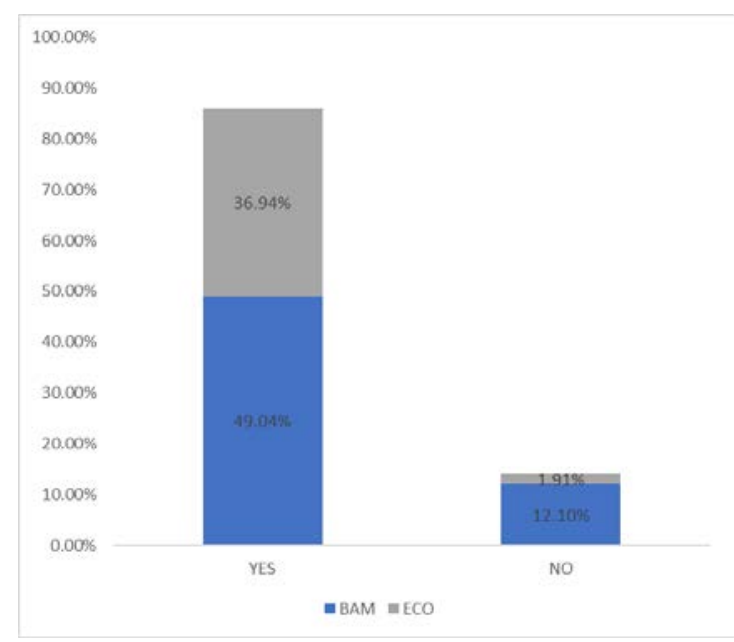

Figure 1. Class attendance according to degree 


\subsection{Survey results}

In the second part of the survey we asked about the degree of usefulness of the teaching material available for the subject "Mathematics I". The material evaluated are the short educational videos, the slides in PowerPoint and "Alternative" materials (collection of exercises, previous exams). Figure 2 shows that, in general, the alternative material is the one most used by students for the preparation of the subject, followed by the available videos and the PPT slides. This profile of preference is similar in both Economics and Business Administration and Management.



Figure 2. Degree of usefulness of the teaching material

Next, the students were asked about the degree of agreement with the use of teaching videos as support material. In general, the students think that the videos are useful for the preparation of the subject (3.51). In addition, they value all the items asked in this section with a score between 3 and 4 points (out of 5), being able to conclude that students value in a positive way many aspects related to teaching videos as support material in the subject. The opinion of the students of both disciplines is very similar.



Figure 3. Degree of agreement with the use of teaching videos

Finally, the overall satisfaction with the teaching videos is measured. In this case, there is a slightly difference between BAM and ECO. The students of BAM value better the use of videos (3.84) compared to those of ECO (3.58). In general, the satisfaction with the teaching videos is good (3.74). 


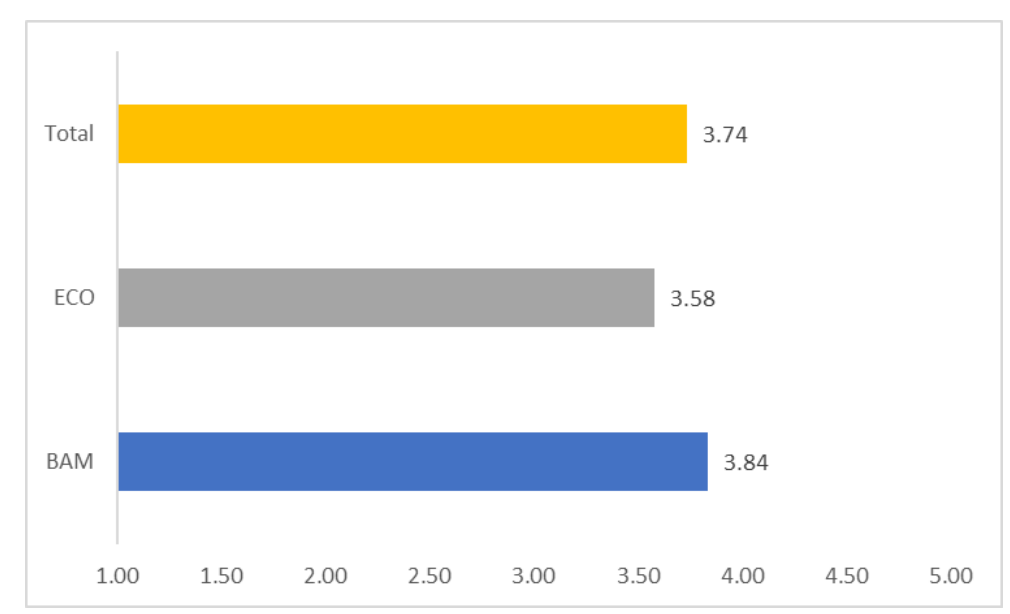

Figure 4. Overall satisfaction with the teaching videos

Taking into account the attendance of students to class, we can conclude (Figure 5) that students who do not attend classes regularly (although in this survey they are only $14.02 \%$ ) value better the teaching videos available in the subject (4.06) than the students who usually attend class (3.69). Although the difference is not very large, it is observed the greater use of the videos by the students who work autonomously the subject.



Figure 5. Overall satisfaction with the teaching videos according to class attendance

\subsection{Aspects of improvement}

In the last section of the survey, we asked about the aspects of improvement to be taken into account by teachers to improve the use of teaching videos available in the subject. Below are summarized the opinions of the students:

- To improve the audio of the videos

- To introduce more exercises from previous exams

- More interactive videos

- To introduce more difficult examples

- Go in-depth on the explanation of the videos

\section{CONCLUSIONS}

The results analyzed in the survey show that in general the teaching videos are useful for the learning of Mathematics I. Although it is true that we can make improvements in the amount of videos by theme and audios. The suggestions of the students show that the videos should focus mainly on the resolution of exercises and examples, and this observation will be taken into account by the teachers of the subject with a view to the elaboration of more educational videos of the subject. 


\section{ACKNOWLEDGEMENTS}

This work has been developed within the research project "Aprenentatge autònom i cooperatiu, i assimilació de continguts mitjançant l'ús de vídeos docents" (Ref.: UV-SFPIE_RMD18-842105) funded by the "Vicerectorat d'Ocupació i Programes Formatius" de la Universitat de València.

\section{REFERENCES}

[1] A. García-Barrera. "El aula inversa: cambiando la respuesta a las necesidades de los estudiantes" in Avances en Supervisión Educativa, 19. 2013.

[2] L. Günter-Huber. "Aprendizaje activo y metodologías educativas" in Revista de Educación, pp. 5981. 2008.

[3] A. García-Crespo, R. Colomo-Palacios and J.M. Gómez-Berbís. "La asignatura Expresión oral y escrita dentro del Grado en Ingeniería Informática adaptado al Espacio Europeo de Educación Superior" in IEEE-RITA Vol. 4, (2). 2009.

[4] P. Fernández-Sánchez, A. Salaverria-Camacho, J. González-Dacosta and E. Mandado-Pérez. "El aprendizaje activo mediante la autoevaluación utilizando un laboratorio virtual" in IEEE-RITA Vol. 4, (1). 2009.

[5] L. Johnson, S. Adams-Becker, V. Estrada, and A. Freeman. "The NMC horizon report: 2014 higher education edition". Austin, TX. Retrieved from http://cdn.nmc.org/media/2014-nmc-horizonreport-heEN-SC.pdf. 2014.

[6] F. Jacobs. "Slagvaardig met ICT; Ontwerpprincipes voor leeromgevingen die professionele digitale competenties van hbo-studenten versterken". Zuyd Hogeschool. 2013. 